\title{
Decolonizing Knowledge, Education and Social Development: Africanist Perspectives
}

\author{
Ali A. ABDI \\ Department of Educational Studies, Faculty of Education, University of \\ British Columbia, Vancouver, BC, Canada \\ ali.abdi@ubc.ca
}

\begin{abstract}
Education is viewed, in general terms, as conductive to social development, intended her as the overall and contextual wellbeing of individuals, communities and societies. Both the ideational and select practices of development emerged and expanded in the past 70 or so years. With colonial education continuing unchallenged in 'postcolonial' Africa, complemented by the importation of prepackaged, non-functional development schemes, the need for knowledge and learning reconstructions are urgently needed in the continent. It is with that in mind that this paper undertakes both historical and actual analysis of the situation, beginning with the critical readings and relevant analytical, counter-colonial problematizations of Eurocentric and by extension, monocentric modalities of knowledge, education and development. To be sure, the arbitrary constructions of both the terra and persona Africana by European and EuroAmerican thought leaders who served as the theoretical vanguards for colonialism and contemporary global capitalist domination has led to, and sustains the current situation with respect to African educational and social development contexts. The appreciation of the historical analysis here, as critically attaching to current situations, is important in achieving the needed counter-Eurocentric discursive formations and related reconstructive educational and development possibilities.
\end{abstract}

\section{Keywords}

Africa - development - Eurocentric - monocentric - knowledge - decolonization 
This paper undertakes a generalist historical analysis of the problematic and colonialist knowledge, educational and development constructions of Africa with the intention of bringing that into select contemporary contexts where those issues are still functional and affecting the lives of people. Indeed, the urgency to critically interact with the early and enduring arbitrary constructions of Africa and its peoples by European and Euro-American thought leaders who served as theoretical vanguards for colonialism and global capitalist domination with both leading us to where we are today with the continent's educational and development situations, is as ever present. The paper does not engage data parametered analysis of the case, but deliberately assumes a quasi-open ended socio-historical and analytical constructions that should minimally accord us an ongoing appreciation of the durability as well as the comprehensiveness (in selective terms) of the issues related to, and emanating from these and attached situations. With this in mind, the main sections of the paper include descriptions, analysis and re-examinations of Eurocentric constructions (monocentric) of Africa and Africans, and from there, the cultural and onto-epistemological deconstructions of African life systems including education and development. To respond to these realities in contemporary critical terms and as central to the perspectives of this work, the focus shifts to the needed counter-monocentric reconstructions and knowledge decolonization possibilities for learning and living wellbeing.

Before the focus on these main block though, perhaps a precis on the somewhat more recent constructions of development/international development which should be analytically necessitated by the fact that in all these colonial and postcolonial relationships, the rationale was, more often than otherwise and with verifiable block inaccuracies, predicated on some form of progress or development. The somewhat formalized presentation of international development was not an agreed-upon global idea or program in either conceptual and/or theoretical writings before the end of the Second World War. Granted that colonialism, with wide its extension into almost all corners of the world by early 2oth century, did make problematic claims on expanding European progress and civilization into different zones of planet earth (Said, 1978; author 2013), the policy as well as the programmatic designs of contemporary international development is about 70 years old. For all pragmatic intentions, that is an insignificant temporal parcel of human history, interactions and achievements. Indeed, the official presentation of international development as something that was to connect diverse zones of the world, with its western-centric prospects, took place during a speech by former American President Harry 
Truman in 1948 on European post-war reconstruction programs when he uttered the words, international development (Black, 2002).

From that announcement in 1948, it was the expansive, indeed seismic shifts in political terms, of the late 1950s into early 196os when so many African countries gained their independence (with postcolonial critical qualifications), that the related conceptual, theoretical and policy expansion of development studies and related educational categories as well as few other sub-disciplinary iterations emerged. Interestingly and analytically attached to the now necessary qualifications on the incomplete projects of African independence, the academic design and formulation of these 'development' related area studies initially started at western universities where even today, most of the now formalized academic programs are located. Previously inherent in the emergence of these international/area studies were the assumed extra-country connections of expertise and need between the West and the rest. With that, the locus of the 'right' education and development were both philosophically and epistemologically constructed with colonized zones such as Africa identified as needing, in almost absolute terms, the adoption of these as in Europe and Euro-America. In his address in 1948, President Truman was clear on the needs of the world's underdeveloped zones and the moral imperative of post-War triumphant America to uplift the lot of the less fortunate. Here, and with early critical queries on the case, few important questions are posed: who actually determines what the right learning programs and related development possibilities are, how are people's needs and expectations ascertained by those outside the concerned areas, and what type of education should be designed and deployed for postcolonial African development? With these questions as partial guiding signposts, I will discuss the issues as arranged and presented below.

\section{Eurocentric and Monocentric Constructions of Africa}

From the perspective of western countries and their citizens, the answers to the above questions were directly given by colonizing Europe and earlier or around that time, at least indirectly accentuated via the writings of some of the most prominent philosophers including the German thinkers G.W.F. Hegel and Immanuel Kant. These two important European thought leaders propagated, within a period of about 50 years a portrait of Africa that was inferior and therefore worthy of theoretical inferioritization, outright oppression and the stealing of its resources (Hegel, 1965; Kant in Eze, 1997). In the so-called postcolonial period, modernist theorists (see Huntington, 1971; Rostow, 1991) added development to the context, rendering in their writings the superiority 
of European/Euro-American ways of life vis-à-vis the rest of the world. The bringing together of these trans-epochal thinkers could create some observational complexities in making sense of the connections here intended. To perhaps be as brief as possible on this point, the perception that some people, Africans in this case, are in need of development, descriptively intended here for the overall wellbeing of societies in their time-space existentialities, does not and did not happen via any concrete and first-witness, location-specific knowledge by European and American thinkers, academics and researchers. Indeed without any evidence, some of Europe's so-termed illustrious philosophers, who are also the direct thought progenitors of American social scientists, the widespread, if categorically false, scribblings about Africa were widely diffused.

The philosophical and by extension, epistemological onslaught on Africa continued over time-and-space with the main attack angles consisting inter alia, as the continent and its people lacking in knowledge, education and development. The triad of knowledge, education and development is important here in that the idea of progress itself is predicated on these constructs and their practical outcomes coming together to ameliorate the lives of people. Yet the Africa which was the cradle of human origins and civilization (Jackson, 1971) was described by Hegel (1965, p. 9) as 'the land of childhood, laying beyond the day of self-conscious history, enveloped in the dark mantle of night'. In terms of Kant (in Eze, 1997), who spoke about earlier notions of global citizenship and cosmopolitanism, he was somehow sure that skin pigmentation represented the final evidence of intelligence and achievement, calling and African person as devoid of those due to his dark skin. Interestingly, the Eurocentric attacks, with even shallower monocentric knowledge categories, was not limited to these but were also expounded, willy nilly, by the so-called French thinkers of liberté, egalité, freternité, including François-Marie Arouet (nom de plume Voltaire, 1826) who went against the racial unity of humankind (Cook, 2005; Sussman, 2014) locating it as not deducible from his knowledge of Africans, and using the bizarre example of the difference between breeds of dogs. The shallowness of this grand Europeans' perspectives should not be lost on anyone as for these then and now popular thinkers, the evidential categories of their exhortations were for them and others, well, self- evident.

For posterity, the human history and contextual reconstructions of these false, racist statements about this ancient continent, which is, for all verifiable considerations, the place that all humanity originated from, are only interesting in the boldness of their self-aggrandizing, false conclusions. By traceable, verifiable extensions on the other hand, the German and French philosophers are all and in bona fide terms, African men. More interestingly, this actually 
exposes the shallow nature of race and racism, both nonsensical socially constructed categories and belief systems that cannot tell us anything about human life and its inherent qualitative realities. Indeed, the categorization of people into different races, is both vertically and horizontally, a reductio ad absurdum conclusion about humankind's origins and genetic composition (Gould, 1985; Cook, 2005; Sussman, 2014). To be sure though, even an analytical bestowing of Africanity on the otherwise bright European men is not an observational or conclusive interest of this paper. I would grant them, without reservation, their desirable and in recent human history agreed-upon, European 'citizenships' that have been especially monocentrically enfranchising for the past $65^{\circ}$ or so years (cf. Abu-Lughod, 1995). The main critical crust of these points is to locate, in socio-historical, educational, and by attached purpose, developmental terms, the main particles of the Eurocentric (Euro-American centric) readings of the world in learning, progress terms and fabricated assumptions, all as explanatory platforms of the education and development damages this and referencing colonial projects did to Africa and its peoples.

Indeed, the minimal descriptive affirmation of the historical formations of the anti-African opinions (and these were nothing more than that) should accord us a higher and more reliable perspective in terms of ascertaining the imposition of non-Indigenous and contextually arbitrary educational and development terms on Africa via colonial epistemic, and onto-epistemological cognitive suppressions. Perhaps one of the most important disquisitions on this is the work of Tanzania's first post-independence President, Julius Nyerere who is widely recognized, not only as an important knowledge systems scholar, but as well, as a philosopher-statesman. Nyerere, perhaps more than any other political leader in the continent, engaged a deep anti-colonial educational and development analysis. In responding to the perforce rescinding of the continent's educational and social development designs and practices, Nyerere, in his oft-referenced essay, 'Education for self-reliance' (1968), post-factually and forwardly analyzed the clash between European ways of being, knowing, learning and situationally advancing vis-à-vis African perspectives of doing all these in precolonial traditional contexts.

\section{3}

\section{Cultural and Onto-epistemological Deconstructions of Vita Africana}

In clarifying the intensity as well as the expansiveness of the colonial encounter in the educational and community wellbeing (developmental) fronts, Nyerere $(1968,1974)$ and Walter Rodney $(1982)$ contextualize the basic tenets of 
teaching and learning as fundamental to people's advancements. These foundational life attachments cannot be detached from the meaningful, sustainable connections with socio-physical environments that inform and situationalize the way people live in both specific and generalized tempo-spatial realities. Stated otherwise, the cultural foundations, reconstructions and durabilities that maintain the community's overall existentialities. In speaking about culture, I have selectively called it everything about people's past, present and futuristic contexts including the way they conceptualize, act upon, and modify their quotidian actions, interactions and outcomes (Abdi, 2006). With this comprehensive reading of culture, which is actually, partially analyzed from Nyerere and Rodney's works, one cannot achieve effective and inclusive systems of education and development when these are, to use a provocatively deliberate stylization for the moment, culturally pauperized. Indeed, a de-cultured education is a de-epistemologized education, thus becoming incapable of responding to the needs of the socio-historical, onto-cultural and politico-economic beings (people in their spatial and temporal locus).

This is precisely what happened with colonized Africa's learning/pedagogical and advancement contextualizations and decontextualizations. These have established and sustained the colonization of the continent's conceptual, cognitive, procedural and programmatic contexts and prospects, which, for all practical intentions, gave us the world we have today. To understand therefore the weight of the issue and speak about knowledge decolonization, one needs to fully appreciate the depth of de-historicized, de-cultured and by direct extension, decontextualized education and development situations where equiticizable global knowledges and meaning-making are nonexistent. Indeed, the case is even starker in current, so-termed Westphalian order, where any global or international learning and development relations are at best rhetorical, if not totally non-sequitur. For contemporary African situations, the issues connects itself well with the problematic of heavily Westerneschewed power relations, which actually assure the problematic continuities of educational and development colonization. Indeed, any educational and developmental connection among Africa and Western countries is nothing as such. What any relations of that nature connote though, especially within the Westphalian political system where the general practice is about the context of country-by-country sovereign claims, is for observational possibilities, unequal cultural, political and economic exchanges. Those exchanges including in knowledge and educational areas, have actually accelerated in the era of extensive and intensive globalizations. Which brings up the important question of how Europe and North America, actually internationalize education and development between themselves and Africa? From this question, other 
queries abound: what types of education are being exchanged, whose learning systems dominate in the global arena, whose development perspectives are highlighted and promoted? In all, whose development education are we talking about?

Procuring complete answers for these important critical questions is beyond the space presumably accorded to this paper, suffice it to say here, and for both observational and analytical facility, the responses, at least some of them, could be obvious. That obviosity could not release us though, from the scholarly devoir of addressing the overall inquiry at hand. Indeed, more questions could be added in terms of the contemporary primacies of culture, linguistic hegemonies, valuation of credentials and the presumed prestige associated with these that are actually monopolized by higher education institutions from Western countries. Here, and to achieve a measure of robustly interacting with these important multiple queries, let me connect to the above-shared problematic and all the false exhortations about Africa, its peoples and development achievements to these points. In essence, the first international education commentators from the west were actually those 18th and 19th century European thinkers (Voltaire, Hegel, Kant, others) who because of their massive intellectual following, achieved two acts there were very bad for Africa. Firstly, they claimed an expertise (albeit a false one) on the continent and its peoples without any real knowledge about either. Secondly, they cemented, again via their thought leadership status, an image (again a false one) of Africa and its peoples as devoid of learning, intellectual and social advancement platforms, thus needing, on all those points, a justification for colonialism and the imposition of Eurocentric and monocentric worldviews, systems of education and schemes of development.

Indeed, such points and analysis are worth repeating and analyzing, even ad infinitum, or at least until the colonial deconstructions and arbitrary, indeed exploitative learning and development situations are epistemically and programmatically, comprehensively rescinded. The immediate rationale for the rescinding, followed by the much needed reconstructions of the situation, again emanate for a major part, from the works of Nyerere and Rodney. In Rodney's outstanding work, How Europe underdeveloped Africa (1982), the case is thickly clear in terms of the wide decommissioning of the continent's systems of advancement that were in place for millennia. These advancements were not limited to one area of study but were, as Semali (1999) noted, attached to almost all aspects of life including social and historical studies, military training, human medicine and veterinary programs, and environmental sustainability seminars. With the horizontal rescinding of these and the imposition of colonial education, languages and attached systems of political 
and economic arrangements, Africa's onto-epistemological existentialities were turned upside down. For a very interesting historico-analytical intervention for me here and having extensively interacted with these, it seems that the writings as well as the pedagogical outcomes of the aforementioned European thinkers where everything African was devalued, negatively deconstructed and deliberately decommissioned, worked to achieve wonders.

This powerful story (in factual blocks) of de-historicization, de-culturation, de-ontologization and by the preceding triad outcome, de-epistemologization of African psychosomatics and precolonial life systems operationalizations are not that detached from the overall colonized world's benighted Mission Civilsatrice (civilizing mission) (see Said, 1993) that was initially applied in French and Portuguese colonies and later expanded into the overall occidentalization of the Orient (Said, 1978). To be sure and for starters especially, this is the essence of mental colonization (see, inter alia, wa Thiong'o, 1986, 20o9; Achebe, 2000, 2009 [1958]; Kane, 2012 [1963]) where the organized attempt to comprehensively de-pattern the cognitive dispositions of Africa (by direct extension, other colonized populations) was designed and extensively (though (not totally) implemented. Understanding, indeed appreciating the psychocultural width of this issue is so essential that it is worth conveying here the deeply subjective manner Ivan Van Sertima (1991, p. 8) descriptively but analytically as well, affirmed the depth of the psychosomatic colonization of the continent and its peoples:

No other disaster with the exception of the Flood....can equal in dimensions of destructiveness the [colonial] cataclysm that shook Africa. Vast populations were uprooted and displaced, whole generations disappeared, European diseases descended like the Plaque decimating both people and livestock, cities and towns were abandoned, family networks disintegrated, kingdoms crumbled, the threads of cultural and historical continuities were so savagely torn asunder that henceforward, one would only have to talk of two Africas: the one before and the one after the holocaust.

In this short historical-cultural/educational perspective, Van Sertima awakens us to perhaps one of the most important requirements to comprehend the intensity as well as the extensity of the multimodal colonial, programmatic formulations and implementations for the minds and bodies of the African people. Indeed, a deeper, unsentimental comprehension (if that is possible with this usually missed or misinterpreted historical-into-actual African realities). The historical-into-actual point in the brackets here is actually as important, if not more important, as 
any other parcel of the writing. To be sure, a full deciphering of cognitive colonization is arguably the most difficult analytical undertaking. The reason for this are multiple but to be as brief as situationally indispensable, one can re-check earlier, seminal works on the processes of psychocultural/mental de-patterning that was unleashed on the basic onto-existentialities of the colonized. In experientially speaking about this, Albert Memmi (1991 [1956]), effectively registered the subjective/inter-subjective and from there, inter-group changes that take place in colonial relationships. Here, the most stark perspective is what Memmi could have described, in my critical interpretation of his writing, the inversely moving lines between the subordinated and the subordinator where slowly the former normalizes, indeed naturalizes his or her 'inferior' psycho-physical being. Indeed, the situation actually gets worse for the subordinated, with as the sorrowful project of self-oppression slowly creeps in, it activates one's own oppression on behalf of his/ her oppressor.

Indeed, to expose the depth of the corporeal 'upheavals' that occurred via the Mission Civilsatrice which has thus far permanentized, not only the miseducation of Africans, but actually and more so the counter-African subjectivities that rendered people into forlornly de-ontologized beings with damaged self-esteem and diminished self-efficacy, is to appreciate it a continuous project. From Frantz Fanon's brilliant anti-cognitive colonization treatise, Black skin, white masks (Fanon, 1967), having revisited the analytical complexity of that work few times myself, it was/is this long ago induced and ongoing onto-epistemological deconstructions that have sustained the absence of viable learning, development and subjective liberation possibilities for the people. Undoubtedly, therefore, this is precisely where the durability of mental/ cognitive/epistemic colonization is directly tied to the educational and development projects that have been prescribed for Africans and for other victims of imperialist Europe, and through both colonial and postcolonial continuation, of America. To take place though and have a practical or programmatic viability, such educational and development colonization has demonstrated a structural deracination of primordial knowledge systems, ways of knowing and being, as well cultural and related advancement possibilities that are inter-generationally conceived, contextually conceptualized and theorized and communally/societally acted upon for the wellbeing of concerned stakeholders. With the rescinding of those possibilities and the absence of viable and socio-culturally responsive learning and advancement reconstructions in postcolonial Africa, a disturbing intergenerational inheritance is harvested, and with this the need for knowledge, and by direct extension, decolonizing educational and social development projects in Africa are needed with quantum urgency. 


\section{Counter Monocentric Reconstructions and Knowledge Decolonization}

With the preceding contextualizations of the problematic constructions of colonial education as learning and development platforms for Africa in the past 200 hundred or so years, without any meaningful policy and programmatic constructions during the postcolonial period, the task of knowledge decolonization for viable community development is not easy. As stated, what is dubbed today development education/international development education is, for all pragmatic considerations, a western-centric form of teaching and learning masquerading as representing the world. Indeed, it is worth repeating the prefix 'inter' in international as a categorical misnomer as there is not any meaningful inter-nations sharing of education, educational policies and programs. Even when we speak about policy borrowing in education (Ball, 1995), the directional simplification can be problematic in the sense that more often than otherwise, the hegemony of the locus of resources amplifies the de-communalization of such policies with the merging global education industry many times controlling the design as well as the outcomes of the case.

In the postcolonial African context especially, any attempts to even minimally renegotiate, let alone critically interrogate, colonial systems of education in their conceptual, content-wise and curricular situations were at best minimal if non-existent in the majority of countries. The exception should be Nyerere's above noted critical readings of the situation, and programmatic responses through his Ujamaa (familyhood in Kiswahili, but much more intended here) programs (Nyerere, 1968) where he set out what he termed as African ways of life, learning and unique ways of development (see also, Nyerere, 1974). We need not spend too much time on the fate of these programs as there are multiple treatises available to consult on the case (McHenry, 1994; Ibhawoh \& Dibua, 2003). Suffice to state here that the authenticity of the projects did not stand a chance against the onslaught of global capitalism which branded Nyerere a socialist/communist and backward thinking. That when, as Ibhawoh and Dibua (2003), in their extensive analysis of Ujamaa as a prospect for African social and economic development, conclusively note that the Tanzanian leader was neither a Marxist socialist nor adherent to any form of communism, but a firm believer in what should be accepted as historical African communalism/social sharing of resources.

At any rate, the failure of African postcolonial knowledge, educational and development decolonization, beyond the policy and programmatic failure of the continent's post-independence governments, carries with it weighty blocks of the above-discussed cognitive and epistemic colonizations that are not easy 
to disengage from. Indeed, the essence of colonialism as a socio/psycho-cultural project, immediately deforming, not only people's mental and behavioral dispositions, but as much their relationship with educational and social development platforms, should indicate the weight of the decolonization project. African decolonization scholars and leaders though, did see early the danger of the systematic circumventing of the decolonization program. In an address at the Conference of the Nationalist Organizations of Portuguese Colonies (CNOPC) in 1965 in Cairo, Egypt, the Bissauian liberation intellectual, Amilcar Cabral, shared at the gathering the dangers of neocolonialism (the combined forces of capitalist globalism, cultural hegemony and economic conditionalities to influence developing countries) this way:

Neocolonialism is at work on two fronts - in Europe as well as in the underdeveloped countries. Its current framework in the underdeveloped countries is the policy of aid, and one of the essential aims of this policy is to create a false bourgeoisie to put brakes on the revolution and to enlarge the possibilities of the petty bourgeoisie as a neutralizer of the revolution.

This situation has been, by open minded hindsight, more or less realized for the West to the extent where especially in the spheres of policy, education and development, the multi-knotted strings of conditionalities have become the stuff of legend between the World Bank (as the guarantor of loans) and its sister organization, the International Monetary Fund (IMF) (together the all too powerful Bretton Woods Institutions) and African countries who seek foreign aid to liquidify their state operations including schooling and social wellbeing. Such early brilliant readings of the possible postcolonial outcomes by Cabral, who also later gave us one of the most original social development re-culturation analysis in his 'Return to the source' perspectives (Cabral, 1981), should be cast along the equally visionary critiques by Frantz Fanon. In his, for my reading, paradigm shifting decolonization disquisition, The wretched of the earth (1968), Fanon foresaw the shallow nationalist rhetoric that was being constructed on robust anti-colonial reeducation and development. As this have turned out, it seems that the well-designed trap of neocolonialism (the deployment of political and economic powers to control weaker countries) has worked wonders for the West, which even if so starkly clear by now, thickens, nevertheless, the iron qualities of the enduring continuities of imperial order by other means.

In different iterations, some of the most prominent thinkers in the areas of cognitive decolonization and knowledge emancipation (see inter alia, wa 
Thiong'o, 1986, 2009; Achebe, 2000; Mignolo, 2012, 2018; de Sousa Santos, 2014, 2018) appreciate, in both retrospective and prospective formats, the complexity of the situation and the longue-durèe processes of liberatory re-epistemologization that are required to achieve counter-oppressive knowledge, learning and social development possibilities. Here, the point and its analytical intentions are not neither particles of negativity, nor observational clusters of despair, but as much as anything else, a pragmatic approach to decipher the depth of the damage, and design, in praxical ways not detached from the way Paulo Freire (2000 [1970]) deployed this, to assure cognitive and extendedly, epistemic liberation via subjective and intersubjective reflective/reflexive analysis into sustainable human liberation.

Again, the complexity of the task for epistemic decolonization, even after so many years of after-physical colonialism, needs to be comprehended well. The issue is not just figuring out the problem, then solving it (if that is so easily doable) by replacing it with Indigenous knowledge systems, learning projects and possibilities of social progress. It is still as much about power relations as it was many years ago. As Mignolo (2018, p. 366) notes, 'focusing on the coloniality of knowledge brings to the surface the entanglement and power differential of knowing and knowledge in the colonies, former colonies, and Western Europe.' He continues to note, as was also alluded to few times above, the endurance of the conceptual into phenomenological threads of super-inferior knowledges and ways of knowing that still color and fabricate the overall relational aspects of the situation. It is with these in mind that the need to immediately disturb and possibly begin to rupture (has to be eventually ruptured) the perennially unequal power relations between the West and the South is so urgent. For me, one important question here should be, where and how to do the critical interrogations, disturbances and the rupturing?

Without staying directly with the above question, it is important to note that despite the apparent difficulty to achieve the project of educational and epistemic decolonization and liberation for the much desired, indeed, acutely needed prospects and projects of social development, the struggle has to continue. Indeed, I do not think there is another venue to achieve development outside the reconstruction of educational and knowledge systems. If anything concretely reliable has been learned about the situation in the past 6 o or so years, it is that African postcolonial life has been at best nominal with Westerncentric learning systems only entrenching epistemic and cognitive colonization that only benefited the political and economic welfare of the elite while suppressing opportunities for the masses. In only paying a cursory glance for now to the Human Development Index (HDI) produced by the United Nations Development Program (UNDP), which measures such things as life 
expectancy, education levels and per capita income, African countries (more so Sub-Saharan Africa) literally, consistently and year-after-year, monopolize the lowest scores in this important human wellbeing measure (UNDP, 2019).

The HDI results are surely not a reflection of human capacity, intelligence or hard work. As stated above, human beings, regardless of where they are in the world, have comparable qualities and capacities (Cook, 2003; Sussman, 2014), and in terms of hard work, one practical suggestion will be to check the average African's determination and energy in Lagos (Nigeria), Dakar (Senegal), or Nairobi (Kenya). The achievement of these fellow human beings to earn their daily bread, so to say, is beyond anything most people in the so-called developed world could imagine. For researchers like myself who are from the continent but have lived in the West for many years, the need to deploy pictorial representations of people in their daily, body-mind challenging drive is not necessary. Nor do we need to conduct shallow interviews on the case. It is starkly in the open, which brings us to another query, which partially emanates from the above point on African people's determination and hard work ethic. To do a decent and for me, inclusive analysis of this, we have to not only tolerate, but embrace the complex but in explanatory-wise, probably ambiguous, especially for new readers of the topic. That is, fully comprehending the interlocking contexts of onto-existential colonization, cognitive imperialism, continually de-indigenizing postcolonial education, all unchallenged by corrupt or inept leadership. Interestingly, the theoretical assumptions of the Westphalian system have been lately problematically mixed with the unequal globalization of the world where African countries especially, while keeping their nominal national sovereign status, are being subjected to the combined forces of exploiting multinationals, and western governments that actually force these economically vulnerable nations to open up even more of their resources and markets for international competition. It is all these forces, among which the schooling system is a major one, that are literally rendering the continent and its people continually dehistoricized, decultured, miseducated and underdeveloped.

So with the situation of educational and development decolonization still suppressed by extra-Africa and within Africa political and economic failures, where do we go from? Certainly, the viability of epistemic, educational and by extension, cognitive decolonization possibilities is the one way to herald practical ways of achieving more community connected platforms of African 
development and wellbeing. By requiring therefore, new and urgent critical responses to the constructs and practices of monocentric knowledge and development, the prospect for achieving multicentric learning and progress possibilities are not impossible. The multicentric point here is crucial at the conclusion of this writing. That is, epistemic, learning and social wellbeing decolonization in Africa should actually be more open-minded and openended boldly embracing what is contextually useful from other knowledge, educational and development systems. Yet, the main objective should not diluted and has to be reconstructed as the achievement of the long-awaited African project of counter-colonial and extensively liberating knowledge, learning and wellbeing achievements. In Ndlovu-Gatsheni (2020) words:

The decolonial turn is part of the longstanding decolonization process in which Africa is enabled to turn a new leaf. At the core of the radical decolonial turn are struggles for the completion of the 'unfinished business of decolonization' as opposed to the colonial/imperial/capitalist/ patriarchal/liberal continuing bourgeois drive, if selectively antithetical to local ways of being, learning and being, towards the completion of the unattainable but in the minds 'unfinished business of modernity (emphases mine)

The idea as well as the pragmatics of reaching out to other epistemologies, methodologies and ways of living that can complement African worldviews and livelihood management systems should be read, indeed, embraced as emanating from, or as an extension of the African humanist philosophy of life known as Ubuntu. Ubuntu, in its simplest interpretation, speaks about our humanization through the humanization of all. Regardless though, and for all pragmatizable possibilities in the case, one good news point is that with respect to the project of knowledge, educational and social development decolonization in Africa, we are, fortunately I should add, at a point of no return, and the move forward has only to be accelerated.

\section{References}

Abdi, A.A. (2006). Culture of education, social development and globalization: historical and current analyses of Africa. In Abdi A., Puplampu K.P. \& Dei G.J.S. (Eds.), African Education and globalization: critical perspectives. Lanham, MD: Rowman \& Littlefield. 
Abu-Lughod, J. (1995). Before European hegemony: The world system AD 1250-1350. New York: Oxford University Press.

Achebe, C. (2000). Home and exile. New York: Oxford University Press.

Achebe, C. (2009 [1958]). Things fall apart. Toronto: Anchor Canada.

Ball, S. (1995). Big policies/small world: An introduction to international perspectives in education policy. Comparative Education, 34(2), 119-130.

Black, M. (2002). No-nonsense guide to international development. London: Zed Books. Cabral, A. (1965). Address to the Conference of Nationalist Organizations of Portuguese Colonies (CNOPC) in 1965 in Caro, Egypt. https://thisisafrica.me/ politics-and-society/remembering-amilcar-cabral-10-quotes/.

Cabral, A. (1981). Unity and struggle: Speeches and writings. Trenton, NJ: Monthly Review Press.

Cook, M. (2005). A brief history of the human race. New York: WW Norton.

De Sousa Santos, B. (2014). Epistemologies of the south: Justice against epistemicide. Boulder, CO: Paradigm publsihers.

De Sousa Santos, B. (2018). The end of the cognitive empire: The coming of age of the epistemologies of the south. Durham, NC: Duke University Press.

Eze, E. (1997). African philosophy: A critical reader. Cambridge, MA: Blackwell.

Fanon, F. (1967). Black skin, white masks. New York: Grove Press.

Fanon, F. (1968). The wretched of the earth. New York: Grove Press.

Freire, P. (2000 [1970]). Pedagogy of the oppressed. New York: Continuum.

Gould, S.J. (1985). The mismeasure of man. New York: WW Norton.

Hegel, G.W.F. (1965). La raison dans l'histoire. Paris: UGE.

Huntington, S. (1971). The change to change: Modernization, development and politics. Comparative politics, $3(3), 283-322$.

Ibhawoh, B. \& J. Dibua (2003). Deconstructing Ujamaa: The legacy of Julius Nyerere in the quest for social and economic development in Africa. African Journal of Political Science, 8(1), 59-83.

Jackson, J. (1971). Introduction to African civilizations. New York, NY: Citadel

Kane, H. (2012 [1963]). Ambiguous adventure. London: Heinemann.

McHenry, D. (1994). Limited choices: The political struggle for socialism in Tanzania. Boulder, CO: Lynne Rienner Publishers.

Memmi, A. (1991 [1956]). The colonizer and the colonized. Boston, MA: Beacon Press.

Mignolo, W. (2012). Local histories/global designs: coloniality, subaltern knowledges and border thinking. Princeton, NJ: Princeton University Press.

Mignolo, W. (2018). Decoloniality and phenomenology: The geopolitics of knowing and epistemic/ontological colonial differences. Journal of Speculative Philosophy, $32(3), 360-387$.

Ndlovu-Gatsheni, S.J (2020). Decolonization, development and knowledge in Africa: Turning over a new leaf. New York: Routledge. 
Nyerere, J. (1968). Freedom and socialism: Selection from writing and speeches, 1965-67. London: Oxford University Press.

Nyerere, J. (1974). Man and development. London: Oxford University Press.

Rodney, W. (1982). How Europe underdeveloped Africa. Washington, DC: Howard University Press.

Rostow, W. (1991). The stages of economic growth: A non-communist manifesto. Cambridge, UK: Cambridge University Press.

Said, E. (1978). Orientalism. New York: Vintage.

Said, E. (1993). Culture and imperialism. New York; Vintage.

Semali, L. (1999). Community as classroom: Dilemmas of valuing African Indigenous literacy in education. International Review of Education, 45(3\&4), 305-319.

Sussman, R. (2014). The myth of race: The troubling persistence of an unscientific idea. Cambridge, MA: Harvard University Press.

UNDP (2019). Human Development Report. New York: Oxford University Press.

Van Sertima, I. (1991). Blacks in science: Ancient and modern. New Brunswick, NJ: Transaction Books.

Voltaire (1826). Essai sur les moeurs. Paris: SN.

wa Thiong'o, N. (1986). Decolonising the mind: The politics of language in African literature. London: James Currey.

wa Thiong'o, N. (2009). Re-membering Africa. Nairobi: Pambazuka Press. 